\title{
The Pelabon Munitions Works and the Belgian Village on the Thames: community and forgetfulness in outer-metropolitan suburbs.
}

\begin{abstract}
West of London in Richmond and Twickenham, 6,000 Belgian refugees developed a flourishing social life, drawn in the context of the national shell drisis" by employment opportunities at the Pelabon Munitions Works. This articte asks why Belgian community life was richer here than almost anywhere else, and explores the significance of refugees' social interaction for their class and other group (dentities. Finally, the article seeks to explain why this vast community became completely forgotten locally.
\end{abstract}

Keywords:

Exile studies, refugee studies, ocai bistory, identity in exile, cross-cultural wartime exchanges, diaspora and transnationalism, forced migration studies

\section{The host communities of Twickenham and Richmond and the Belgian arrivals}

The first Belgian refugees reached Richmond and Twickenham in late August 1914, and entered a complex social tapestry. Graphically described by Belgian writer Paul Gérardy under the alias "Justin Wallon", the community became known by the title of his book Une Cité Belge sur la Tamise ("the Belgian Village on the Thames"). ${ }^{1}$ The Belgians of Richmond and Twickenham became the prime node of a chain of Belgian communities along the River Thames, a true Belgian corridor stretching west from Chelsea Embankment to Thames Ditton, Weybridge and beyond. This article repositions the history of the Belgians in Richmond and Twickenham in the overall civilian history of the First World War and thus 
aims to overcome the fate that had been the burden of this long-forgotten history: forgetfulness.

Twickenham and Richmond adjoin along a three mile (five $\mathrm{km}$ ) stretch of picturesque Thames-side landscape. In 1914 the two towns were not integral parts of the metropolis but transport was good and the centre of London only eight miles $(13 \mathrm{~km})$ away. Today Twickenham and Richmond are united within the London Borough of Richmond upon Thames, but in 1914 they were separate units. The Borough of Richmond had greater prestige from its Municipal Charter; its poor relation Twickenham was still merely an Urban District Council. Like today, the two towns were separate parliamentary constituencies and were in different counties, Surrey and Middlesex respectively. These administrative dichotomies must be remembered when considering the history of the First World War Belgian community, which straddled the two towns.

The host populations of Richmond and Twicken fram were broadly speaking privileged. The upper and middle classes (the aristocracy, professions and high finance) were represented in both, but within the rigidly hierarchicanEdwardian-society of the time, Richmond always held the edge in numbers and distinction. Housing for middle class families of different levels had been built around 1900 gust outside the two town centres, and working class housing usually a bit further avay. The suburbia of Richmond and indeed Twickenham stood for stability and respectability.East Twickenham was essentially middle class, but like Richmond not entirely so: working-class housing existed in pockets everywhere for those servicing the needs of their "superiors". Working-class men were mostly employed in trade or market gardening, while women worked mostly as domestic servants. Small-scale industrial workshops were tucked away everywhere, but there was no large-scale manufacturing industry. Richmond (particularly) - with its great parks and its riverside, Victorian boathouses and tiers of rowing boats for hire - served as utopia for its residents and riverside pleasure-ground for Londoners of all classes. However, all the characteristics that were cherished about suburban Richmond and Twickenham were challenged in the First World War by the arrival of Belgian refugees. ${ }^{2}$

Belgians entered Richmond and Twickenham in three waves ${ }^{3}$. The first immigrants, reacting between early August and late September to the initial German invasion, were few in 
numbers and largely self-sufficient. The second wave fled the fortified port of Antwerp, the final sanctuary, before it fell on October $9^{\text {th: }}$. Deployed to Twickenham-Richmond by the War Refugees Committee in London between October and January 1915, these Belgians were supported by public funds or private philanthropy. In the third and largest wave locally, from January to autumn 1915, employment opportunities at the new munitions works opened a period of self-reliance and community-building.

For the first two of these waves, the Belgian story in Richmond and Twickenham was much the same as elsewhere. The third wave was different, and here the Belgian community of Twickenham-Richmond has a distinctive history.

\section{The Pelabon Works, Self-Reliance and Community}

The Pelabon company was the creation of industrial baron Charles Pelabon: not Belgian but French, though Belgian-trained and at the start of the war running a mining equipment factory south of Brussels. When the Germans approached Brussels at the end of August 1914, Pelabon moved his establishment to just north of Antwerp and briefly produced munitions there; then, just before Antwexp's fall on October $9^{\text {th }} 1914$, he left for England taking his senior managers and some hundred skilled workers with him. Immediately seeking a new site for operations, he found an empty riverside boathouse, not in Twickenham but in nearby Teddington. ${ }^{4}$ Accerding to Wanlon's account Pelabon was producing munitions here by the end of October, just three weeks after reaching England, presumably relying on his own imported workers. 5 The space too small for his ambitions, Pelabon bought an uncompleted skating-rink with surrounding riverside lands in respectable East Twickenham and started building, causing outrage by his proposed industrial development.

The location of the Belgian factory and community has often been misreported. The Pelabon Munitions factory was in East Twickenham, a mile distant from Twickenham itself and just across the river from Richmond. East Twickenham residents have often historically claimed the title of Richmond for themselves: East Twickenham social life has for centuries looked east, across the river to Richmond, more than to Twickenham, and "Richmond" was a more prestigious name to give to the outside world. Belgian writers from 1914 onwards were just as equivocal: 
A factory in Richmond, city of summer, town of pleasure-making, almost a spa town! Desecration! But this did not last long. Just like everyone else, the founder of the Twickenham factory appreciated the beautiful surroundings where pressure of chance events had led him to settle.... (our italics / translation). ${ }^{6}$

Wallon described the Belgian community in its developed form and usually spoke of "Richmond and Twickenham", but ill-informed successors were less meticulous. This has produced a misconception that the Belgian factory and community were in Richmond. The more accurate term "Twickenham-Richmond" is always used here. ${ }^{7}$

Twickenham District Council, in agreement with Richmond Corporation and local residents were opposed to Pelabon's proposed industrial development, The local authorities set a condition that the site be vacated three months after the war; Pelabon declared this impossible, offering five years instead. Two days later Pesabon sent a solicitor's letter warning Twickenham Council that;

the urgency of meeting the demands of the altied Governments cannot be overstated at the present time and, unless facilities can be given by the Council the situation will be calculated to very seriously inmpede the exeeution of the Government requirements and prejudice the prosecution of the war. ${ }^{8}$

Pelabon now offered to sell thesite to the Council within three years: the Council responded by making it subject to a Town Planning Scheme with a condition for dwelling-houses only; even the skating-rink building was to be removed. Pelabon proposed a further plan which the Council - with the press excluded and after Council solicitors' amendments - agreed formally on February $22^{\text {nd }} 1915$. This approved the factory for the manufacture of war materials "not [...] of an explosive nature" in return for a Council option to buy the land and buildings in 1921 for $£ 3,000 .{ }^{9}$ Tacit agreement evidently existed earlier as the Council discussed drainage and sewerage for the works, routinely, on January $21^{\text {st }} .{ }^{10}$ Production of munitions started some time in February $1915,{ }^{11}$ pre-dating the countrywide surge in war industry production after the Shell Crisis.

In May 1915 increasing shortage of high-explosive shells for the British Army led to failure in the Battle of Aubers Ridge in France. Back home this forced the creation of Coalition Government which quickly established a Ministry of Munitions. The new 
department was headed by David Lloyd George and spurred a surge of new munitions factories nationwide. ${ }^{12}$ Belgian "able" men in Britain formed a useful force of labour: for instance, the numerous Belgians brought into the specially-built community of Elisabethville staffed the National Projectile Factory in Birtley, near Gateshead. The situation could not be more different for the Pelabon Belgians, most of whom had either rejoined their former employer or been employed before the Shell Crisis. This is not to say the Pelabon Factory was not responding to a shell shortage in winter 1914, especially since it was producing almost entirely for the Belgian Government which had lost all its homeland facilities. Shells remained the main output of the factory together with gun parts, ${ }^{13}$ but not predominanty hand grenades as has been stated in some recent coverage. ${ }^{14}$.

The Pelabon Works are mentioned intermittently in the Twickenhan Council minutes from February 1915, mostly over routine matters such as new buildings or road works which caused no dissention. The council also referred complafits frombocal residents about, for instance, excessive smoke or litter on the tiverside, to which Pelabon responded constructively. Twickenham Council generally discussed more substantive issues with Richmond Council, which was invariably predispesed to prevent anything 'detrimental to the amenities of the neighbourhood'

For six months or so, Pelabon 8 ontinued manufacturing from his Twickenham buildings in parallel with the Teddington wokkshop. No doubt some Teddington staff transferred over at once, and the workforce also absorbed recent Belgian incomers to Twickenham, Richmond and surroundings. During 1915 Pelabon had built four more workshops on his extensive site, creating an enterprise which was large even by English standards. ${ }^{16}$ By July 1917, the Pelabon works employed 1,705 Belgians, compared to 1,469 at the Belgian munition factory of Kryn \& Lahy in Letchworth. At the same time, the highest number of Belgians employed in a British factory was 5,797 for the entire chain of Vickers plants and 1,335 for Armstrong Whitworth in both Glasgow and Newcastle. ${ }^{17}$ In Twickenham-Richmond by mid-1915, staffing was also apparently problematic since Pelabon recruited directly from Belgian refugee camps in the Netherlands, while other workers came from occupied Belgium. Pelabon also established his company offices across the river, this alone carrying the Cité Belge into Richmond. ${ }^{18}$ 
The "Cité Belge myth" maintains the Pelabon workers were all Belgian, but this is not strictly true: small numbers of English of both sexes were employed, and at least one Dutchman. ${ }^{19}$ There could therefore have been other nationalities; nevertheless the workforce was predominantly Belgian and the factory was understood by all to be a Belgian enterprise. ${ }^{20}$ The oBelgian "family" atmosphere within the original workforce seems to have survived and seems to have absorbed the newcomers as they came along. A similar "family" atmosphere reportedly developed in the self-contained Belgian community of Birtley, ${ }^{21}$ but no other factory was entirely Belgian-owned and no other factory brought its core working community with it. ${ }^{22}$ However, Wallon's view of the Pelabon workforce as one happy family is simplistic, as trades unions were active in raising salary issues at the factory. In 1917 the company was forced to align overtime rates with those paid in neighbouring factories. ${ }^{23}$ As discussed by Amara a year earlier a militant female worker, Angèle Sabatier, had called for collaboration ffom all refugee workers in the country to win equal pay for women. ${ }^{24}$

The Pelabon workforce at full capacity is genepally estimated at nearly 2,000: mostly men, but perhaps some 500 women (though this nurpber may be too high). ${ }^{25}$ There is contradictory information as to the employment of Belgian women in English factories generally. The Belgian factory at Birtle for instance employed only men, which was typical of Belgian-owned factories in Britain during the war, not least because often the employees were Belgian soldjers nolonger fit for service at the front. However, there is evidence of women in at least three other factories as well as at Pelabon. ${ }^{26}$ Cahalan speaks of a slow progression of Belgian women into the British workforce, including munitions work, and Storr mentions fernale munitions workers without enumerating them. ${ }^{27}$ At Pelabon, however, there was a substantial contingent of female workers, apparently from quite early on. Some of the women were known locally as "canary girls" because of their yellowing $\operatorname{skin}^{28}$, a change usually attributed to liver damage arising from exposure to explosives. Work with explosives would however have breached Pelabon's agreement with Twickenham Council. It is more likely that Pelabon's shells were filled with their explosive elsewhere and that these wqmen were handling the cordite propellant ${ }^{29}$

Contemporary photos show Pelabon staff organised into "departments" of 15 to 40 workers, sometimes including women, engaged in different manufacturing processes. ${ }^{30}$ Heavy work operations were evidently all-male and delicate operations all-female; a few 
operations were mixed, with men predominating. Foremen and managers were usually male (photos show just one female factory supervisor with only a fraction of female managers); and all the directors and very senior staff were men. The male workforce included a number of rehabilitated soldiers, often amputees, deployed by the Belgian Army as their continuing war service. This was not exceptional: the Armstrong-Whitworth factory in Birtley was staffed entirely by rehabilitated solders, and certain other establishments in smaller part. ${ }^{31}$ In Twickenham, though, there was also a detachment of Belgian soldiers billeted under the command of a Captain in an ordinary house opposite the factory, with responsibility for quality control in the Pelabon Works and other factories manufacturing for the Belgian Government. ${ }^{32}$

Class and linguistic divisions within the factory were complex, reflecting long-standing contingencies and new realities. Back in Belgium, Wallonta had held precedence both in terms of its heavy industry and through its command of the upper levels of national life; Flemish-speakers hoping to compete had to forego their ldentity and conduct their working lives in French. ${ }^{33}$ This pattern seems to have been replidated in the Pelabon Works. Most of Pelabon's original skilled workers may well also havebeen French-speaking from Wallonia, but this balance changed as the workforee expanded. The unskilled workers who were now recruited and trained, many if not mostly Flemish, recreated the class structure existing in Belgium by providing the workilg-elasp Flemish-speaking layer at the base. Like both the English and the self-syfficient Belgians, the workers' social class determined where they lived: the comfortably off in East Twickenham and pockets of Central Twickenham; ordinary working men in St Margarets, the back of Central Twickenham and outer Richmond; the few very wealthy in Richmond. The shop floor also employed many Frenchspeaking middle-class Belgians who could not practise their own professions in Britain: Wallon indicates a blend of mutual incomprehension and new-found respect between oldstyle and neophyte labourers. ${ }^{34}$ The fallen bourgeoisie did not necessarily abandon their class status outside the factory: the Labeye family with five wage-earners in Twickenham lived well and returned after the war to their commercial operations in Antwerp ${ }^{35}$. 
Wallon's estimate of the size of the Belgian community of Twickenham-Richmond as about 6,000 is widely quoted ${ }^{36}$. There is no independent corroboration: the figure is broadly consistent with a factory workforce of some 2,000, allowing for workers' dependants, but the reality is more complex. ${ }^{37}$ Not all local Belgian residents worked at Pelabon: some for instance were retailers and others were self-sufficient. Equally, some Pelabon workers probably commuted in from outside the Twickenham-Richmond areas: if these compensated for each other, perhaps the 6000 figure is plausible. Incontrovertibly, though, TwickenhamRichmond housed a substantial Belgian community, large enough to attract the notice of the host community and claim a presence in the Belgian exile press such as De Stem Uit België en De Dageraad.

The sheer numbers and the factory culture are two features that seem to have combined to create an unusually cohesive refugee community. Wallon provides a snapshot:

A Belgian who passed Richmond Bridge or walled through the streets around the factory at the times of the workers' arris and departure [...], might well believe he was the victim of hallucination, as he might have the feeling of being suddenly transported to an industrial townin the envirens of Liége [...] You hear the singing, drawling tones of the language everywhere, as cheerful and good-natured as on the side of the River Meuse [. Nens-sellers cry out l'Indépendance, la Métropole, le Journal, le Matin, le Vingtieme stècle..... Groups stand at street corners and chat gaily. Here and there we hear Flemish or French. But it is Walloon which dominates and one does not hear a) word of English. ${ }^{38}$

This Walloon writer may minimise the Flemish presence here, though in the earliest days, when the largely francophone engineers and managers roamed the area, the Flemish presence was perhaps less.

Regardless of linguistic differences or class divides, the impact of the Belgian community changed the whole look of the area. Some St Margarets streets were occupied entirely by Belgians. ${ }^{39}$ In East Twickenham, rows of shops at the foot of Richmond Bridge were now Belgian: grocer, bookshop, cobbler, jeweller and clock-maker; butcher, tea-house, dressmaker and milliner. Across the river in Richmond was a Belgian patisserie of some years' standing, a new tobacconist and toy-maker; also two new cafés, one of which served as a brothel. ${ }^{40}$ 
Although initially higher-class Belgian refugees joined the English at concerts and lectures the enlarged Belgian community developed a life of its own. At the centre was the munitions factory. Charles Pelabon, who himself lived apart in a grand house in East Sheen overlooking Richmond Park, ${ }^{41}$ was a paternalistic employer who supported his workers, providing schools, a pharmacy, and even lavish funerals for workers killed in industrial accidents. He also demonstrated his interest in the community in February 1915, albeit as a condition in his contract, ${ }^{42}$ when he agreed to pay the Council component for educating the Belgian children of Twickenham, who were scattered across several public schools. In January 1916 they were brought all together into a special Belgian Department at Orleans Elementary School in St Margarets. ${ }^{43}$ Upon recommendation by the Rev Canon English, Marie de Vos became headmistress. Another four Belgian teachers and one English unqualified teacher joined them; all were women. Meanwhile, Pelabon extended his beneficence beyond his workforce and set up two schools in Richmond: Écols Alsext-Esizabeth, a kindergartenprimary behind the town, and École Léopold-Charles, a private boys' secondary on Richmond Green, subsidised to an unknown amount but charging $£ 1$ a month. ${ }^{44}$ Precise information is lacking, but this payment would have challenged working-class Belgians. Workers' children from Richmond attendedPelabon's primary school but (it is tempting to conclude) rarely the secondary schor, and possibly few girls of any class received secondary education at all. The English themselveg were little different at this time.

Belgians were typically cornmitted Catholics who regularly attended church. This differentiated them from the dominant local Church of England tradition, though there was always a strong contingent of English Catholics in both Twickenham and Richmond. It is not known whether this common church allegiance brought Belgians into meaningful contact with their English fellow-parishioners. Wallon, however, describes the English appreciation of the "pretty" sight of Belgian girls in white dresses processing from the riverside to St Elizabeth of Portugal Church up Richmond Hill. ${ }^{45}$ From East Twickenham, the exceptionally Protestant Major Prayon Van Zuylen became a pillar of the Congregational Church, also on Richmond Hill. Most Twickenham Belgians went to St James' Catholic Church in Strawberry Hill. Later in the war a "Scheut Father", Father Joseph Flameygh, was active in Twickenham, though whether in the church or school is uncertain; certainly the Parish Priest, 
Canon English, was incumbent before, during and after. ${ }^{46}$ Children in Richmond were visited regularly by Father Allegaert, attached to the Richmond Catholic Church. ${ }^{47}$

The Pelabon Factory provided a focus for much of Belgian community life. Wallon, who noted "the invariably harmless, and frequently useful, passion of the Belgians for forming societies," speaks of more than a dozen groups; pre-eminently the Pelabon Works Philanthropic Association, noted particularly for providing the "Soldier's House" behind Richmond Hill for Belgian soldiers on leave from the front. ${ }^{48}$ There was an employees' afterhours social club, also an orchestra and a choir, which both performed in London with acclaim. There were separate Walloon and Flemish dramatic clubs reportedly attracting full audiences and devoting their profits to charity, and there was a sports club, offering boxing, wrestling and gymnastics, with bowls and dancing for entertajinment. Incongruously, perhaps, there was also a troop of Belgian Boy Scouts who, since they met on Richmond Green, were presumably based in the Pelabon-supporte boys sehool. ${ }^{49}$ L'Indépendance Belge reports similar cultural and sporting events from among other substantial concentrations of Belgian munitions workers, for instance from Birtley or Letchworth, but noticeably more such events each month from Twickenham-Richmond. ${ }^{50}$ However the frequency of advertisements, usually ery week, outstripped those of other communities, even the more active. This suggests there was a particular vitality in the TwickenhamRichmond community. As in mand places elsewhere, the community was no longer a recipient but a dispenser of philanthropy, both from Pelabon societies and other groups with only tenuous connections to the factory. ${ }^{51} \mathrm{~A}$ matter of scale, perhaps, but TwickenhamRichmond evidently had a particular cultural richness. In the absence of fuller information, it can be hypothesised that there was something different about the Twickenham-Richmond Belgian community. Arriving much earlier than their compatriots elsewhere, its members perhaps included a higher proportion of self-sufficient and more educated Belgians. For professional Belgians seeking such employment as they could get, the Pelabon Factory was one of the few openings early on, and later it was perhaps, so near the metropolis, simply more appealing.

As both Wallon and local press reported, Belgians socialised in the Belgian cafés and the English pubs. Belgians apparently had difficulty coming to terms with the notion of "licensed premises" but their cafés learned to live with it, apart from the occasional lapse. 
Nevertheless the Belgian "cafés" remained centres of low-grade disorder and focus of English indignation, the Richmond café-brothel on Hill Rise being particularly prone to court summonses. ${ }^{52}$ According to Wallon, Belgians and English were indeed largely living parallel existences. The Belgian, Richmond and Twickenham élites met on some formal occasions and neighbours of all classes exchanged pleasantries, but Belgian entertainments - concerts, plays and other events in the community halls of Richmond and Twickenham or the Pelabon premises $^{53}$ - were now separately their own. ${ }^{54}$ The early honeymoon had passed with both sides criticising the other in their newspapers; otherwise, they left each other alone. ${ }^{55}$ The possible consequences of this for the refugees' identity is intriguing as they were "Belgians" to the English, not necessarily to themselves: Wallon's ardent patriotism of $1917^{56}$ belies the famous earlier advice of Jules Destrée in 1912 (translated): “Sire, you reign over two peoples. In Belgium there are Walloons and Flemings.

There are no Belgians." ${ }^{57}$ No need for setting this quvtation selparately - integrate it onto the text. Note too, the longer quotations should not ha yeinerested commas around them.

The Twickenham-Richmond Belgian refugee population was therefore segregated from the wider community and internally divided Wallon writes frankly about mutual difference, acknowledging that Belgians' failure to sollow English norms of respectability or observe the Sabbath shocked many of theirhosts. Belgians spoke loudly in public with animated gestures; some chewed tobaccgor spet in public, and women went out without hats! Wallon probably downplays the English horror at the arrival of Belgian horse butchers. Belgians on their part found English reserve and etiquette comic but they generally cared little for English opinionand lived their own way of life as they best could. ${ }^{58}$ Wallon concluded that ructions between the two groups were rare, and attributes this to the predominantly middle and lower-middle class population of Twickenham-Richmond. ${ }^{59}$ But brief remaining glimpses of local working-class opinion show more bitter feelings: envy of the Belgian men and women's standard of living and resentment of Belgian men working in safety here while the English men folk were at risk on the Belgian front. ${ }^{60}$ Added to that were regulated pay rates for Belgian factory workers, both men and women, wages for Belgian men and women that at least matched the pay of their English counterparts.

As the war continued, there were increasing complaints about Belgians taking over available housing. Twickenham had a lot of empty properties at the start of the war, but this did not 
last forever. Nevertheless Twickenham-Richmond avoided the community conflict over housing which arose elsewhere, for instance in Fulham or further away in Birtley or Barrow. ${ }^{61}$ Bearing in mind the predominantly working-class population of Fulham and its more acute housing shortage, Wallon's hypothesis about the reason for Belgians' failure to follow English norms is attractive. ${ }^{62}$ Moreover the friction over employment which arose, for example in Manchester, did not occur in Twickenham-Richmond, where there were relatively few working-class English male competitors. ${ }^{63}$

It is not known whether local Belgians "of quality" continued to socialise with their English peers. However, individual friendships were certainly formed between Belgians and English. The King family of Seymour Gardens, Twickenham, took in Belgians Mr and Mrs Albert, and esteemed them enough to visit them after the war. ${ }^{64}$ There was fraternisation producing at least one illegitimate child, and at least two marriages. Francois-Emile Van Sichem, a rehabilitated soldier working at the Pelabon Works, marmed Annie Howes of Central Twickenham in 1917; they returned to Belgivin and had gon in 1918, but divorced in 1925. ${ }^{65}$ More successfully, Edouard ("Teddie') Labeye married his English sweetheart Nellie Hammerton, in 1922; their son.also "Teddie", was born in 1923 in Belgium and visiting continued each way. The Englis family remain in touch with Teddie "Junior" (aged 94). ${ }^{66}$ François Cole in neighbouring Teddington married an English woman and stayed on after the war, raising a famjiy and rymining an electrical repair shop for many years. ${ }^{67}$ However, information about individual Belgians in Twickenham-Richmond is scant, partly because nter-community marriages were not necessarily conducted in Catholic churches where records can be traced. Most probably there were a number of other stories like these, known at the time to immediate friends and neighbours; nevertheless, TwickenhamRichmond was not left with a living tradition about Belgians living in their midst.

The social and cultural activity of the elite and middle class refugees, both inside and eoutside their ocal community which by 1917 seemingly had confidence in itself, can be seen as "the symbolic complexes of their social networks" which, as Abner Cohen elucidated, claim and consolidate a complex blend of class and group affiliations ${ }^{68}$. Meanwhile, the main external connection for the working-classes probably came from their trade union involvement in the Workers' Union. This too crystallised and advanced their class position. ${ }^{69}$ Full analysis of the symbolic construction of local, national and sub- 
sectional identities in the face of host categorisations, along the lines of Anthony P. Cohen or Richard Jenkins, must await more detailed information. ${ }^{70}$

\section{Twickenham-Richmond in the Belgian refugee diaspora (the Thames corridor and beyond)}

Various war-time reports show that roughly 70,000 Belgians lived in or near London, ${ }^{71}$ forming not a demarcated community but a fragmented presence. ${ }^{72}$ There were localities to the south-east which were not homogenous entities: the Belgian presence in Dartford, Crayford, and Woolwich, also at Bromley and Chislehurst, was more an amalgamation of pockets. However, from Chelsea Embankment westwards, an entire corridor of Belgians had formed, roughly along the River Thames. From Crosby Hall in chelsea; over Fulham Broadway and Lillie Road, Shepherd's Bush, Hammersnuith and Goldhawk Road, Chiswick and into Ealing and Brentford in the northwest of London, and southwest into RichmondTwickenham and yet further up the river to places like Thames Ditton and Weybridge; thousands of Belgians had settled. ${ }^{73}$

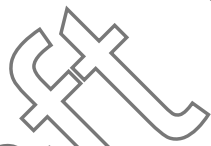

No Belgian settlement was a closed system and the interaction of the TwickenhamRichmond community with giners nearand far, was inherent to its functioning. The elite Twickenham-Richmond-exiles focused their lives in London, became tied in with the Belgian Legation near Sloane Square - and lusciously sampled the many associations and charity events that sparked on the back of the Belgian refugees. Middle and working-class Belgians followed the elite and travelled into London for activities as diverse as banking, liaising with military authorities about enlisting or tracing soldier-relatives, or just for social purposes. Here they might meet Belgians living in Central London, the south-east "pockets" and the south-west "Thames Corridor",or Belgians visiting London from further afield. They gathered in the West End theatres, which sometimes, like the Criterion, included Belgian plays in their repertoire, and they patronised the many pubs in the city centre and further afield: the Blue Anchor in Hammersmith and Drayton Court in West Ealing, not far from the offices of the Belgian Red Cross. They joined social clubs, often ostensibly professional or philanthropic. In some cases they established a specific Richmond-Twickenham branch which socialised with a national network; in one case, they established part of the group's 
national organisation in East Twickenham. ${ }^{74}$ The adult leaders of Richmond's Belgian Boy Scouts took their troop to congregate with the other Belgian troops in Britain: the fact that all of these came from the Thames Corridor confirms that this area had a commonality of its own. ${ }^{75}$

\section{Departure, aftermath and forgetfulness}

Little presence of this concentrated Belgian community remained after the First War. Government action compelled most of the Twickenham-Richmond Belgians to return home quickly, and by the end of March 1919 almost all the workforce had departed. By then the host community was eager to see them leave. ${ }^{76}$ The Belgian Department at Orleans School closed in February 1919 with only thirteen children still on the roll. Richmond Council discussed the suitability (or otherwise) of accommodation occupied by Belgians for returning soldiers and their families. ${ }^{77}$ Pelabon continued operating a general engineering works, intended as permanent, but withdrew after the 1920 recession. His plant was auctioned in 1923 and the factory and lands sold in 1925 . Pelabon finally left the area in 1925 to pursue an illustrious career in French industry. ${ }^{7}$

The Belgians had "melted like snow, leay ing so little trace", and by the mid twentieth century the Belgians had been almost entirely forgetten, despite the arrival of a few thousand new Belgian refugees during the $\$$ econd $\mathrm{W}$ orld War. They too, quit Britain equally rapidly. ${ }^{80}$ Pelabon's roadside by/dings remained in light industrial use but the riverside building in 1928 became the internationally-known Richmond Ice Rink. The Ice Rink and most of Pelabon's buildings survived until the early 1990s when they were demolished for a luxury housing development. ${ }^{81}$

Given the proportion of the Belgian community in exile, the size of the Belgian corridor along the River Thames and the noted presence of thousands of Belgians in TwickenhamRichmond, it remains an enigma that this community was forgotten so completely. Various causes can be suggested. Firstly, the intense local charitable effort to support destitute Belgians dropped away during 1915 just as the initial wave of empathy towards Belgian refugees was waning (see figures on British press coverage on Belgians below). In Twickenham and Richmond, most local refugees were by then largely self-sufficient and the refugee support committees were almost redundant. As in the rest of England, philanthropy 
was becoming generally more preoccupied with the welfare of serving soldiers and war wounded, with Belgians in Britain less the focus of concern. ${ }^{82}$

The structures of Belgian employment and education are a second factor in accounting for this forgetfulness. Workers were mostly segregated in the Pelabon factory or other Belgian establishments, and the union representatives overseeing their interests were Belgian, not English. By the end of 1915, too, almost all the Belgian children were educated separately, receiving their own curriculum with strong input from the Catholic Church. Although relationships developed at times between Belgians and English, these were peripheral. When the Belgians left, there were relatively few inter-personal connections to keep memories alive.

Thirdly is the significance of the local press. Nationwide the visibility of the Belgians diminished during the war itself, but in Twickenham-Richmond hey were nothing if not visible. Nevertheless local newspaper coverage dechiped steadily over the war years and the later references were virtually restricted to court reports. ${ }^{83}$ The apparent disappearing act indicated by a search of the Richmond Frergld between 1914 and 1919 is consistent with the frequency of mentions of 'Belgian reforgees' in the contemporary local press around the country, as given by search of the British Library Newspaper Archive. This shows a striking downward trend: 82.2\% of all đyartime meentions were in 1914 and 1915.

\begin{tabular}{|c|c|c|c|c|c|c|c|}
\hline & 1914 & 1915 & 1916 & 1917 & 1918 & 1919 & Total \\
\hline $\mathrm{BLNA}^{84}$ & 9,950 & 8,923 & 2,029 & 764 & 838 & 456 & 22,960 \\
\hline $\mathrm{RH}^{85}$ & 41 & 84 & 74 & 49 & 36 & 12 & 296 \\
\hline
\end{tabular}

A comparison of frequency of references to Belgian refugees in local Richmond and national newspapers, 1914-1919

In Richmond, mentions of Belgians plummeted after they mostly left in 1919, and from then on, the local press did nothing to promote remembrance among the English.

The Belgians also became excluded from record, not only literally through often discarded archive material, but also in living memory. ${ }^{86}$ People researching their First World War family history commonly find that relatives who returned from the front remained silent for 
the remainder of their lives. Likewise, it can be argued that family stories about accommodating and entertaining Belgian refugees on the home front - Belgian refugees who were the embodiment of why Britain had gone to war in the first place - disappeared into the same silence. This is compounded in Twickenham-Richmond by the transience of the population, where few of today's aspirational "spiralist" families have lived in the area more than twenty years. ${ }^{87}$

Despite some of its unique features, the history of the Belgians in Twickenham-Richmond shares one important characteristic with the entire sojourn of Belgians during the First World War: the Belgians came, and went, with on the face of it no striking legacy. It could even be said that the key aspect of the mass migration has been the forgetfulness. Put simply, in Twickenham-Richmond the Belgians were forgotten because the memory had no purpose and because there was almost no-one left to remember them. Recently, East Twickenham and Richmond upon Thames have re-discovered this menfy and in the light of suggestions by (for instance) Winter and Mulvey that the British mantipulate accounts of the First World War to promote national identity, ${ }^{88}$ it would be interest)ng to explore how the borough and "village" might respectively benefit from this narrative. In the meantime, this account of the Twickenham-Richmond Belgians controutes to overcoming the legacy of forgetfulness.

\footnotetext{
${ }^{1}$ Wallon. Cité Belge. Lon'́n and Brussels: 1917.

${ }^{2} \mathrm{Hug}$, On The Edge, 58.

${ }^{3}$ Baker \& Coltman, "East Twickenham: the Mystery of Belgium upon Thames", Borough of Twickenham Local History Society Newsletter 166, April 2014. Baker, "Belgian Refugees in Richmond during the First World War", Journal of the Richmond Local History Society, 35, May 2014, p.7-17, online https://www.academia.edu/ (accessed July 20, 2015)

${ }^{4}$ Used for manufacture of river-launches and motor-boats. The company (Hesse \& Savory) had dissolved in 1913, and an ex-partner was now developing the first Aston Martin in the Fulham-Chelsea area. "The Origins of Aston Martin", The Aston Martin Magazine, http://astonmartin.blob.core.windows.net/magazine/issue21/feature-centenary-early-years.html (accessed June 29, 2015). Pelabon lived initially at the Savoy Hotel and it is tempting to imagine him networking with English engineers in West Central London. This was conceivably the link which brought him to the Twickenham-Richmond area.

${ }^{5}$ Wallon, Cité Belge, 19.

${ }^{6}$ Wallon, Cite Belgé: 22-23.

${ }^{7}$ Even the exhibition Exodus: Fleeing the War at the Museum Aan De Stroom in Antwerp, May 2014 March 2016, labelled both the community and the factory as "Richmond".

${ }^{8}$ Twickenham Urban District Council, Minutes of the Proceedings at the Meetings of the Urban District Co Twickenham Urban District Council, Minutes of the Proceedings at the Meetings of the Urban District Council, kept from 1889 to 1925 at Local Studies, Richmond, October 1914 - April 1915, p.705. "Special Meeting of the Urban District Council of Twickenham”, 3rd December, 1914, p.704-706.
} 
${ }^{9}$ Ibid, 26 November 1914, p.698; 3 December 1914, p.703-710; 31 December 1914, p.782-783. A report by the Twickenham Town Clerk is not available and its contents not now known; however details are given in the surviving "Report of the Highways Committee to the Town Council, $13^{\text {th }}$ April, 1915", Borough of Richmond (Surrey) Agendas, Minutes and Reports, from 9 Nov, 1914, to 12 Oct, , 1915, kept from 1891 to 1965 at Local Studies, Richmond: see Minutes of Council Meeting $13^{\text {th }}$ April, 1915, appended item F; see also p. 63 and 72 ,

${ }^{10}$ Twickenham Urban District Council, Minutes of the Proceedings, op. cit. Highways, Works and Fire

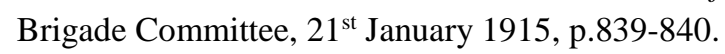

${ }^{11}$ Wallon, Cité Belge, 19.

${ }^{12}$ Cahalan 1977, 271. Declercq, 'Lost and a Translation', 151.

${ }^{13}$ The Pelabon Works (advertisement) in Maeterlinck et. al, La Belgique en Guerre, p. $20-21$.

${ }^{14}$ First perhaps made on a website of Richard Meacock, a Richmond Ice Rink campaigner. The website is no longer accessible but is reproduced on http://icerinx.com/meacock.html (accessed June 29, 2015). The error was repeated on the Twickenham Museum website http://www.twickenham-

museum.org.uk/detail.asp?ContentID $=336$ (accessed June 29, 2015). It was then widely promulgated by the $\mathrm{BBC}$ in publicity for their World War One At Home series in 2014. This is no longer accessible online, but is confirmed online by a Richmond local newspaper, "Richmond grenade factory fedtures in BBC World War One stories" (Your Local Guardian, February 18, 2014), http://www.yourlocalguardian.co.uk/news/11016603.Richmond grenade tactory teatures in BBC World War_One_stories/ (accessed June 29, 2015).

${ }^{15}$ Re. a proposed river wharf at the site: Borough of Richmond, of dit. Minutes of the Council Meeting, $13^{\text {th }}$ June, 1916, p.77-78. Reports to the Town Council, $13^{\text {th }}$ Jupe, 1916, Highways committee, item H, p. 2.

${ }^{16}$ Amara, L'Épreuve de l'Exil, 214-215.

${ }^{17}$ Comité Officiel Belge, Rapport à Monsieur Le Ministre, 1918, 205, 107, 112-114.

${ }^{18}$ The Pelabon offices were set up in eighteenth century Heron House, preserved by architect Quinlan Terry in a 1987 riverside development.

${ }^{19}$ Personal communication, November 24, 2914, to Heler Baker from Jan Meeuwsen, grandson of Dutchman J. A. Meeuwsen, employed at the Pelabon Works 1916-1921.

${ }^{20}$ Although most refugees in Britain in the prisst World War were Belgian, no record is made of the presence of for instance Serbian refugees in the Tuickenlam-Richmond area.

${ }^{21}$ Whereas the Belgian comantunity in Twickenham-Richmond lived physically among the English community and was visible in the hocal area through its Belgian shops alongside the English outlets, the Belgian community in Bittley was physically contained, as was its cultural life. For an appreciation of the self-contained Belgiannes of the Bittley munition workers see Camille Fabry, Nos 'Hors-Combat', 54-87.

${ }^{22}$ Primary sources, such as the-1917 report by the Comite Officiel Belge and the 1920 Report on the Work Undertaken..., describe Pelabon and Kryn \& Lahy in Letchworth as enterprises of equal size, but they were not because the Twickenham-Richmond community was twice if not three times the size of Letchworth. Other Belgians commuted in and out of Letchworth for employment and education purposes (Heron, Guests of Nation, 15), and there is evidence for a cultural scene almost as lively as in Twickenham-Richmond. Twickenham-Richmond contrasts even more with other factories employing Belgians, e.g. Birtley or Goldhawk Road, West London.

${ }^{23}$ Eekelers, Een Belgische vakbond, 42-44.

${ }^{24}$ Amara, L'Épreuve de l'Exil, 211, 227.

${ }^{25}$ Wallon, Cité Belge, 29, estimates 700. However the Report on the Work Undertaken, gives the combined number of women working at the Pelabon Works and the (Belgian) Kryn \& Lahy factory as 675: our own estimate assumes $a^{2} / 3$ weighting in favour of the larger Twickenham factory.

${ }^{26}$ Ibid. Varlez. Les Belges en Exile, 262.

${ }^{27}$ Cahalan, Treatment of Belgian Refugees, p.21. Storr, Excluded from the Record, 69.

${ }^{28}$ The women workers were from different sections, therefore not all were "canary girls", but their existence is confirmed in contemporary texts e.g. Groves "Childhood in Twickenham", II,6.

${ }^{29}$ Personal communication from Barry Buttenshaw, former bomb disposal expert, $8^{\text {th }}$ March 2016. 
${ }^{30}$ For example, a group of female workers from the website Postcards Then And Now:

http://postcardsthenandnow.blogspot.com/2011/04/twickenham-middlesex-pelabon-works-1914.html

(accessed June 30,2015), and a similar photo of male workers shared with Helen Baker privately by the same webmaster. The collection of photos held by the Royal Museum of the Army and Military History, Brussels (B.1.90 and B.138-139), includes nearly 30 shots of the Pelabon workshops, many showing the personnel (male/female, manager/worker).

${ }^{31}$ Fabry, "Nos 'hors-combats' “, 9-10, 37-45. Varlez, Les Belges en Exil, 262, 280-281.

3222 Cambridge Road. The "Moscow Archives" indicate that these soldiers also oversaw quality in the other factories producing munitions for the Belgian Government. (The "Moscow Archives" are a collection of correspondence between the Belgian Government and their munitions suppliers in Britain, held by the Royal Museum of the Army and Military History, Brussels, for the months April to December 1915 as Box 4620.

${ }^{33}$ Klein et. al, "A waffle shaped model ...", 10, 18. Witte et al. Politieke Geschiedenis, 109-116. De

Schaepdrijver, Het Koninkrijk België, 29-37. Dumoulin, Nieuwe Geschiedenis van België II, 705-712.

Reynebeau, De Geschiedenis van België, 102-105. Declercq, 'Belgian Refugees in Britain', 58.

${ }^{34}$ Wallon, Cité Belge.

${ }^{35}$ Helen Baker and Valerie Coltman's interview of July 11, 2013, with Edouard Labeye, Brussels, son of the Edouard Labeye employed at the Pelabon Works 1915-1918.

${ }^{36}$ Wallon, Cité Belge, 35

${ }^{37}$ This may one day be achieved if all the information on Belgian Refuged Registration Cards at the Belgian National Archives can be analysed.

${ }^{38}$ Wallon, Cité Belge, 46.

${ }^{39}$ Ibid, 26

${ }^{40}$ The Belgian shops in East Twickenham are evidenced in two phofographs held by the Royal Museum for the Army and Military History, Brussels (B-1-90-70-51 (and B-1-90-70-52). The collection also holds a covering note by the donor, René L Stéyart, son of Jules Steyeyrt, Administrative Director at the Pelabon Works 1916-1918; the note states that the fathefwas given the album of photos of the factory and its surroundings by Charles Pelabon in 1918. K (elas s s Dixectory includes within Richmond: the Belgian Tobacco Company, 17 Hill Rise; Belgian Toy Factory, 3 Kew Road; and cafés at 8 Paved Court and 16 Hill Rise; none are included in Kelly's after 1918. Betgian catéculture in Richmond is described in "Belgian café's in our midst" (Richmond Herald, Octobgr (6, 1917) and an English critical view is given in a semi-editorial piece, "Bad Behaviour" (Richmonall(terald, April 20, 1918). "Raid on Belgian café" (ibid, April 21, 1917) reports a conviction of the proprietors of the 16 Hill Rise café for brothel-keeping. "A row in a café" (ibid, May 26, 1917), and "Méée in a Belgian Café", (ibid, July 7, 1917), report more general disorderly incidents at these premises. Licensing issues are reported in "Police Raid at Hill Rise. 'Café' without a licence" (ibid, April 1, 1916) and "Paved Courr Café Raided by Police" (ibid, June 24, 1916).

${ }^{41}$ Kelly's Directory, volumes $1916-1923$. The size of the house is indicated by photographs held in Local Studies, Richmond: "Fife Road, East Sheen, No.8, "Parkholme" (LCF 8804 and 8807)

${ }^{42}$ Pelabon was genuinely philanthropic in the old-fashioned sense, but he was a hard-nosed business-man too. The Council required him to make these payments so they were not entirely altruistic.

${ }^{43}$ Twickenham Urban District Council, op. cit, October 1915 - April 1916. Education Committee: November 20, 1915, p.91-92; December 23, 1915, p.148-149; January 24, 1916, p. 189.

Borough of Richmond (Surrey) (1915), p.3; Twickenham Urban District Council Minutes, $26^{\text {th }}$ November $3^{\text {rd }}$ December- $21^{\text {st }}$ January 1915.

${ }^{44} \mathrm{He}$ also provided a third school in Chiswick, apparently without compulsion.

${ }^{45}$ Wallon, Cité Belge, 49.

46 "Scheut Fathers in Twickenham". The Tablet, January 17,1920, http://archive.thetablet.co.uk/article/17thjanuary-1920/24/news-from-the-dioceses (accessed June 29, 2015). "Parish History", Church of St James, http://stjamestwickenham.org.uk/about-us/parish-history/ (accessed June 29, 2015). The Scheut Fathers belonged to the Missionary Congregation of the Immaculate Heart of Mary in Scheut-les-Bruxelles. In 1920, after presumably residing at the previous Scheut community at 63 Stamford Hill (London N16), Father Flameygh became Procurator (Superior) of the new Scheut community in Regents Park Road (London NW1) devoted to the spiritual care of the "many Belgians still remaining in London". 
47 "Death of Belgian priest", Richmond Herald, March 1, 1919.

${ }^{48}$ Wallon, Cité Belge, 50.

${ }^{49}$ Wallon, Cité Belge, 53.

${ }^{50}$ L'indépendance Belge, examined for the days 19 November, 1914, to 25 November, 1918.

${ }^{51}$ Wallon, Cité Belge, p.50. "Ligue des Patriotes de Richmond" (L'indépendance Belge, 15 November, 1915). "Un club ouvrier philanthropique" (ibid, 8 June, 1916). "Nos ouvriers généreux" (ibid, 2 Decembre, 1916). “Au Cercle des Anciens Combattants de Richmond” (ibid, 14 April, 1917). "A Richmond: La soirée du Kunst en Liefdadgiheid" (ibid, 4 Decembre 1917).

52 ibid, 36-37. Also "Police Raid at Hill Rise. 'Café' without a licence” (Richmond Herald, April 1, 1916).

"Paved Court Café Raided by Police" (Richmond Herald, June 24, 1916).

${ }^{53}$ Eg. "Aux usines Pelabons" (L'indépendance Belge, 16 March, 1917). "Le 14 July aux Usines Pelabon" (ibid, 26 July, 1917). "Concert extraordinaire à Richmond” (ibid, 19 October, 1917). "La société Kunsten Liefdagighied à Richmond” (ibid, 21 Decembre, 1917). "Les sports à Richmond” (ibid, 16 January, 1918). "Grand soirée artistique à Richmond" (ibid,18 Javier, 1918). "Concerts et Théâtres: à Richmond" (ibid, 1 \& 2 March, 1918). "Sous-Comité de la Ligue des Patriotes de Richmond. Manifestation patriotique" (19 September, 1918). "Hippodrome Theatre Richmond. La Revue Anglo Belge" (21 September 1918). ${ }^{54}$ For example, “Aux usines Pelabons" (L’indépendance Belge, 16 March, 1917). "Le 14 July aux Usines Pelabon" (ibid, 26 July, 1917). "Concert extraordinaire à Richmond” (ibid, 19 Qotober, 1917). "La société Kunsten Liefdagighied à Richmond" (ibid, 21 Decembre, 1917). "Les sports à Richmond” (ibid, 16 January, 1918). "Grand soirée artistique à Richmond" (ibid,18 Javier, 1918). "Concerts et Théâtres: à Richmond" (ibid, 1 \& 2 March, 1918). "Sous-Comité de la Ligue des Patriotes de Richmond. Manifestation patriotique" (19 September, 1918). "Hippodrome Theatre Richmond. La Revue Angla Belge" (2) September 1918). ${ }^{55}$ Illustrated in the responses of British and Belgians to a violent guarrel between two Belgian women from St Margarets, which ended in court. Mathile Huesay, a turner at the Relabon factory, was allegedly attacked by Marie Boussard, who pulled her hair and scratched he face. A witness from Liège, asked why he did not separate the two women struggling on the ground, said this was rather customary there, upon which the summons was dismissed. Middlesex Chronicle, 19 August 1910,8.

${ }^{56}$ Wallon, Cité Belge, 6.

${ }^{57}$ Destrée, "Lettre au Roi" ("Letter to the King), (Rzvue de Belgique, 15 August 1912).

${ }^{58}$ Wallon, Cité Belge, 32-33; 42-43.

59 ibid, 43.

${ }^{60}$ Groves, "Childhood in Twickenham". $\mathrm{HI}, 5$ and Cowley, "Daddy is a Soldier", 117.

${ }^{61}$ Fulham was significant for its a ute housing shortage, with employed Belgians renting homes the English could not afford. In Blackpooi, Belgians kept rents of seaside hotels high because their rents were paid for them. In Barrow, Belgans started busting locals from council houses and English soldiers at the front nearly returned in protest. English in Birtley were envious of Belgians in the bespoke village of Elisabethville, enjoying domestic amenities Which they lacked themselves. Knox and Kushner, Refugees in an Age of Genocide, 57. Declercq, "Belgian Refugees in Britain", 58. Englander, 'Landlord and Tenant in Urban Britain', 382-385.

${ }^{62}$ Wallon, Cité Belge, 32-33; 42-43.

${ }^{63}$ Dockers in Manchester for instance protested against Belgians being employed. "Belgian Labour, the Manchester Dockers Protest" (Manchester Evening News, January 15, 1915).

${ }^{64}$ Personal communication to Helen Baker from Janice Newell, grand-daughter of Mr \& Mrs King, 35 Seymour Gardens, Twickenham, August $3^{\text {rd }}, 2013$.

${ }^{65}$ Personal communication to Helen Baker, 1 April 2014, from Judith Mahoney, grand-daughter of FrancoisEmile Van Sichem, Storekeeper at the Pelabon Works.

${ }^{66}$ Interview with Edouard Labeye, op. cit, note 33

67 Personal communication from Alan Robb, a schoolfriend of François' son, 10th November 2015.

${ }^{68}$ Cohen, Two-Dimensional Man, p.65-67, 131-134, 136-138.

69 "Belgian Workers Organised" (Richmond Herald, 21 August, 1915. "The Workers Union" (Richmond Herald. 9 October, 1915)

${ }^{70}$ Cohen, Symbolic Construction of Community, p.12,15,19,104-118. Jenkins, Rethinking Ethnicity, p. $56,105,170$ 
${ }^{71}$ By the end of August 1917, 172,298 Belgians were living in Britain, of which 69,562 stayed in London. Twickenham-Richmond Belgians were included in the London figure. 3,988 Belgians were living in Hertfordshire. Comité Officiel Belge, Rapport à Monsieur Le Ministre, 94.

${ }^{72}$ For example, hundreds of Belgians were employed by the Home Office and several hundred by railway companies that operated from London.

${ }^{73}$ Comité Officiel Belge, Rapport Addressé à Monsieur Le Ministre, 91-114. "Keep The Country Busy, Heston and Hounslow Belgian refugees" (Middlesex Chronicle, May 8, 1915). "Belgian refugees" (Middlesex Chronicle, June 26, 1915).

${ }^{74}$ The Cercle des Anciens Combattants' section for documentation and information, in East Twickenham: "Combattants et Anciens Combattants" (5 November, 1918).

${ }^{75}$ Kensington, Fulham and Wimbledon: Kensington, Fulham and Wimbledon: "Les Boys Scouts"

(L’Indépendance Belge, February 27, 1917); "Nos Boy Scouts" (ibid, June 6, 1917).

76 "Rumours and Facts" (Richmond Herald, November 30, 1918).

77 "Housing in Richmond" (ibid, February 1, 1919)

${ }^{78}$ Several references to these sales were recorded in the Yorkshire Post and Leeds Intelligencer in the period between November 24, 1925 and November 27, 1925.

${ }^{79}$ For a consideration of Pelabon's life and career see d'Ambrières, 'Les Pelabon....'.

${ }^{80}$ Unattributed undated memo in Richmond Local Studies. Helen Baker's personal experience confirms the story was completely forgotten by 1950 . Niche memories lingered among residents vith local family connections and surviving members of the professional skating community, both elderly and very few. Richmond Local Studies and the Borough of Twickenham Local History Spcrety could produce meagre records when asked.

${ }^{81}$ Notes from Bob Carr, Greater London Industrial Archalogy Society, available from http://www.glias.org.uk/news/150news.html\#B (accessed June 29, 2015)."Richmond Ice Rink", http://www.twickenham-museum.org.uk/detail.asp?ContenkD=336 (accessed July 2, 2015), is accurate on the residential development.

${ }^{82}$ Grant, Mobilizing Charity, p.163-170. For Ridomond: Richmond Herald examined for the weeks 6 January, 1917, to 26 April, 1919.

${ }^{83}$ Richmond Herald examined for the weeks January 6, 1917 to April 26, 1919.

${ }^{84}$ British Library Newspaper Archive, online, http://www.britishnewspaperarchive.co.uk (accessed July 2, 2015). Admittedly, whether one woufd refert the Belgians as refugees after two or three years remains an important but difficult variable to gauge. More than 100 local newspapers printed articles on the Belgians in Britain, the most frequent examples being in the Bristol Western Times, the Yorkshire Post and Leeds Intelligencer and the Exetex and Plymouth Gazette.

${ }^{85}$ Richmond Herald examined for the weeks August 29, 1914, to April 26, 1919.

${ }^{86}$ This is also the point of view of Storr, Excluded from the record, 2. Also, of the estimated 2,500 local Belgian relief organisations, the archive material of a little over 200 are kept in the Imperial War Museum archives. With more archive records from Britain and Belgium added, only a mere 250 are accounted for. To date, the archive records of the Belgian community in Twickenham-Richmond have not yet resurfaced.

${ }^{87}$ Watson, 'Social class and mobility', 147.

${ }^{88}$ Winter, Remembering War, Paul Mulvey, British National Identity.

\section{Bibliography}

A Vision of Britain through Time. Online, http://www.visionofbritain.org.uk/. Online (accessed July 5, 2015). Amara, Michael. Des Belges a l'Épreuve de l'Exil: les réfugiés de la Première Guerre mondial, France, Grande-Bretagne, Pays-Bas, $3^{\text {rd }}$ edition. Brussels: Editions de l'Université de Bruxelles, 2008.

Brown, Maysie, ed., Barnes and Mortlake Past - with East Sheen. Barnes and Mortlake History Society, undated.

Cahalan, Peter. The Treatment of Belgian Refugees in England during the Great War. McMaster University, 1977. Online, https://macsphere.mcmaster.ca/handle/11375/15514?mode=full (accessed July 4, 2015) 
Comité Officiel Belge Pour l'Angleterre. Rapport Addressé à Monsieur Le Ministre de l'Intérieur, le 31 August 1917. Brussels: Imprimerie Belge, 1918.

Cohen, Abner. Two Dimensional Man: an Essay on the Anthropology of Power and Symbolism in Complex Society. Abindon, Routledge \& Kegan Paul, 1074.

Cohen, Anthony P. The Symbolic Construction of Community. London, Tavistock Publications, 1985.

Cowley, Minnie. My Daddy is a Soldier: a working-class family in the Lloyd George era, edited by Annette Kuhn. Unpublished, undated. Kept at Local Studies, Richmond.

d'Ambrières, René. 'Les Pelabon: entre industrie et patriotisme, ou des ANF aux Mureaux en passant par Londres', Bulletin de la Sabix 48, 2011. Online http://sabix.revues.org/1007 (accessed July 1, 2015). Declercq, Christophe. 'Lost and a Translation: Belgians in Britain during the First World War', Through Other Eyes, the Translation of Anglophone Literature in Europe (Richard Trim and Sophie Alatorre eds), Newcastle, Cambridge Scholars Press, 2007.

Declercq, Christophe. 'Belgian Refugees in Britain 1914-1919', The Low Countries, vol.22. Rekem: Ons Erfdeel, 2014.

De Schaepdrijver, Sophie. De Groote Oorlog, het Koninkrijk België Tijdens de Eerste Wereldoorlog.

Amsterdam/Antwerpen: Atlas, 1999.

Dumoulin, Michel, Emmanuel Gerard, Mark Van den Wijngaert, Vincent Dujardin. Nieuwe Geschiedenis van België II, 1905-1950. Tielt: Lannoo, 2006.

Eekelers, Willem. Een Belgische Vakbond in Engeland. Antwerpen: Excelsior, 1919.

Englander, David. 'Landlord and Tenant in Urban Britain: the politifs at housing reform 1838-1924', unpublished $\mathrm{PhD}$, University of Warwick, 1979, 382-385.

Fabry, Camille. Nos Hors-Combat à Elisabethville-Birtley (1stedn. Bruxelles, Les Chants de l'Aube, 1919. Gladstone, David, ed., Civitas Choice in Welfare No. 47. Trowbridge: The Cromwell Press, 1999. Online, http://www.civitas.org.uk/pdf/cw47.pdf (accessed July 5, 2015).

Groves, Julia. "A childhood in Twickenham 19ק6-1918", Barough of Twickenham Local History Society Newsletter, no.70 (1982). Copy kept at Locast Studies, Richmond.

Heron, Pat. Guests of the Nation: the Story of Ilford Belgian Refugees 1914-1919. Ilford: purplewhiteandgreen, 2010.

Hug, Rupa. On The Edge: The Contested Chltures of English Suburbia. London: Lawrence \& Wishart, 2013. Jenkins, Richard. Rethinking Ethnigits: Arguments and Explorations, $2^{\text {nd }}$ edn. Los Angeles and London: Sage Publications, 2008.

Klein, Olivier, Licata, Laurent, Mar der Sinden, Nicolas, Mercy, Aurélie. "A waffle-shaped model for how realistic dimensions of the Belgian conflict structure collective memories and stereotypes", in Memory Studies, January 2012, 5, 1, 16-31

Knox, Katharine and Tony Kushner. Refugees in an Age of Genocide, London, Routledge, 1999.

Lewis, Jane 'The voluntary sector in the mixed economy of welfare', in David Gladstone ed. Before Beveridge: welfare before the welfare state, Civitas Choice in Welfare No. 47, , 10-17. Trowbridge: The Cromwell Press. Also online http://www.civitas.org.uk/pdf/cw47.pdf (accessed July 4, 2015).

Moorcroft Wilson, Jean. Virginia Woolf's London: A Guide to Bloomsbury and Beyond. London, I.B. Tauris, 2001.

Maeterlinck, Maurice, Buysse, Cyriel \& Dumont-Wilden, L. La Belgique en Guerre. Brussels: Ernest Van Hamme, 1918,

Mulvey, Paul. "British National Identity and the Great War", academia, edu, 2015.

https://www.academia.edu/1002125/British_National_Identity and the Great_War_lecture. Online

(accessed July 5, 2015).

Report on the Work Undertaken by the British Government in the Reception and Care of Belgian Refugees.

London: His Majesty's Stationery Office. 1920.

Reynebeau, Marc. De Geschiedenis van België in Woord en Beeld. Tielt: Lannoo, 2005.

Storr, Katherine. Excluded from the record: women, refugees and relief, 1914-1929. Oxford: Peter Lang. 2009.

Varlez, Armand, Les Belges en Exil. Burssels and London: Libriarie Moderne, 1917. 
Watson, W. 'Social mobility and social class in industrial communities' in Closed Systems and Open Minds, edited by Max Gluckman. Edinburgh: Oliver and Boyd, 1964.

Wallon, Justin. Une Cite Belge sur la Tamise, London and Brussels, Librarie Moderne, 1917

Wiesel, Elie, 'Myth and History'. Myth, Symbol, and Reality, edited by Alan Olson. Indiana: University of Notre Dame Press, 1980.

Winter, Jay. Remembering War: The Great War between Memory and History in the 20th Century. New Haven \& London, Yale University Press. 2006.

Witte, Els, Jan Craeybeckx, Alain Meynen. Politiek Geschiedenis van België van 1830 tot Heden. Antwerpen: Standaard Uitgeverij, 2005.

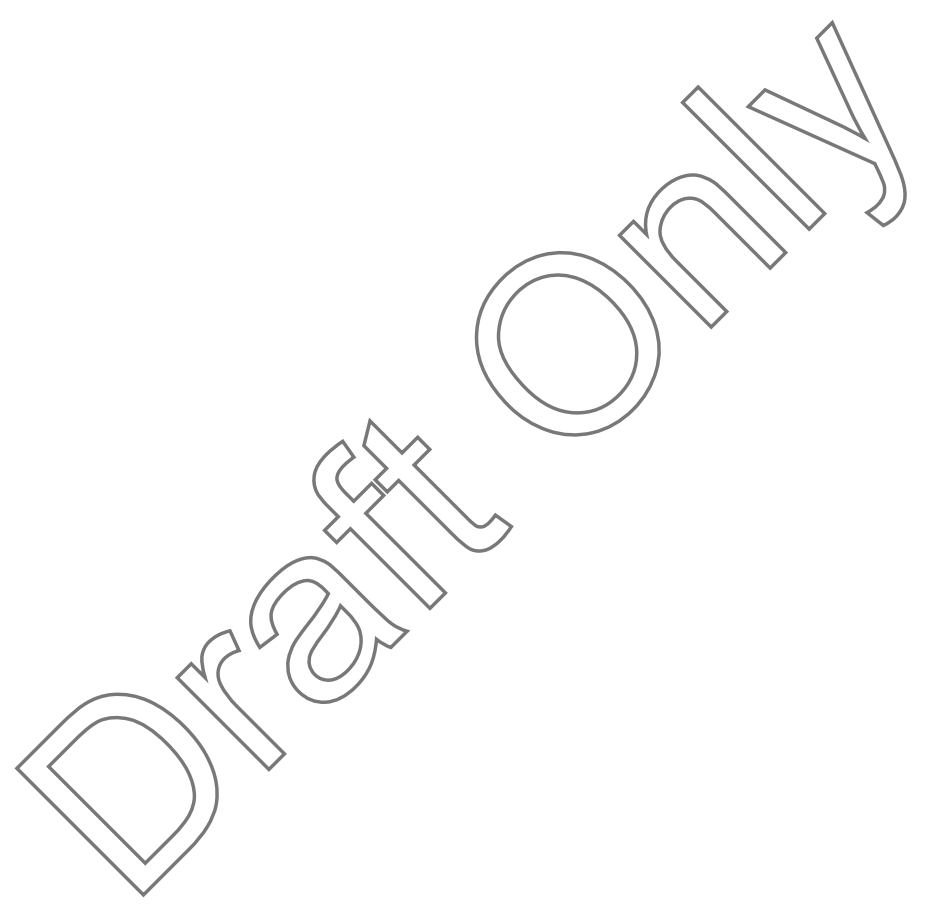

